\title{
協同課題における貢献量明確化行動と負債感
}

\author{
O山本 晶友 ${ }^{1}$ 樋口匡貴 ${ }^{2}$ \\ (1 上智大学大学院総合人間科学研究科 2 上智大学総合人間科学部) \\ Key words: indebtedness, exchange relationship, communal relationship
}

二者間の関係性には交換的関係と共同的関係がある(Clark \& Mills, 1979)。交換的関係とは, 相手からの返報を期待し て恩恵を施しあう関係である。これに対し共同的関係とは, 相手の欲求に応じて恩恵を施しあう関係である。

これらニつの関係性のどちらであるかによって，二人の貢 献量の合算で報酬が決まる協同課題における行動が異なる。 Clark（1984）は，協同課題を他人同士で行わせる条件（他人 条件）と，友人同士で行わせる条件（友人条件）を設定して 実験を行った。他人条件は交換的関係，友人条件は共同的関 係であると意図されていた。課題は数字行列の中から特定の 数列を見つけ出しペンで印を付けるものであり, 2 人が見つ けた数列の合計で報酬が決まるとされた。実験の結果, 他人 条件では 2 番手として課題を行う際に 1 番手であるパートナ 一と異なる色のペンを選ぶ傾向があったが，友人条件ではそ の傾向が無かった。すなわち，返報が重視される関係性であ る交換的関係においてのみ，自身の貢献量を明確にしようと する行動を行う傾向が強かった。

この先行研究は, 関係性が違えば行動の違いが生じると考 えているが, 生起する負債感が強ければ, 関係性が違ってい ても同じ行動が取られる可能性がある。ここでの負債感は「自 己の恩恵受領に伴って他者に生じたコストに対するネガティ ブな感情的反応」と定義する。これは，一般に「申し訳なさ」 と表現される感情（蔵永・樋口，2011）である。パートナー の貢献量が自身よりも極めて大きかった場合，貢献量を無視 した均等な報酬分配を行うと, 自己の恩恵受領に伴って他者 にコストが生じる。こういった状況で感じる負債感が強い程, それを回避するために貢献量明確化行動が行われやすくなる と予測できる。そこで本研究では，この負債感と貢献量明確 化行動の関連を検討する。

\section{方 法}

分析対象者 都内の学生 20 名 $\left(M_{\mathrm{age}}=20.40\right.$, 女性 17 名)。 実験計画 負債感の高低（高群 / 低群）を参加者間要因 とする 1 要因 2 水準の実験計画であった。従属変数はパート ナーと異なる色のペンを選ぶか否かであった。

手続き 参加者には友人との二名で実験に参加させた。冒 頭で以下の教示を与えた。「今一緒に参加している友人, また は別のフロアにいるもう一組の参加者（実際はいない）の一 方とペアとなり 2 種類の課題を行う（実際は 1 つ目の課題で 実験終了)。課題ごとに, ペアとなった 2 名のうち一方が 1 番手, もう一方が 2 番手となる。1 番手となるか 2 番手とな るかは, 1 つ目の課題と 2 つ目の課題の間で交代する。報酬 はペアの成績の合計が多いほど多くなり, 各課題終了後に 2 番手にまとめて渡される。報酬の分配は 2 番手が行う」。以上 の教示の後に, 用紙に署名をさせ, 封筒に入れて回収した（署 名封筒)。次に 2 名を別々の個室に隔離し，参加者それぞれに 1 つ目の課題である数列課題の説明を行った。数列課題とは, リストにある数列を別紙の数字行列の中から 4 分以内になる ベく多く見つけ出し印を書き込むものであった。練習として 例題を解かせた後に, 本番では何本の数列を見つけられると 思うかを記入させた。次に, これから本番を行うと伝え, 参 加者それぞれに「2 番手になった」と教示した。ここでペア
となるパートナーの名前が書いてある署名封筒を渡し, 中身 を確認させた。この時参加者に, 予め用意した架空の氏名の 署名封筒を渡す場合と，一緒に参加した友人の氏名の署名封 筒を渡す場合とを同数つくり，パートナーが他人であると認 識する参加者と友人であると認識する参加者の両方をつくり 出した。これは負債感に分散をもたせることが目的であった。 4 分待機した後に, 参加者それぞれの予測の本数より 3 本多 い数列を発見してある状態の課題用紙を, パートナーの解答 であるとして参加者それぞれに渡した。この解答用紙は青色 かピンク色のペンのいずれかで解答を書き込んでおいたもの であった。課題用のペンとして青色のペンとピンク色のペン を渡した。ここで参加者がパートナーと異なる色を選ぶか否 かが従属変数であった。その後「相手と同じ色のペンを選ぶ ことは相手に申し訳ないと感じた」という項目に1「全く当 てはまらない」から 7「とてもよく当てはまる」で回答させ 負債感得点を測定した。

\section{結果と考察}

Table 1

負債感の高低と選んだペンの色の関係

\begin{tabular}{|c|c|c|c|}
\hline & \multicolumn{2}{|c|}{$\begin{array}{l}\text { 選んだペンの } \\
\text { 色ごとの人数 }\end{array}$} & \multirow{2}{*}{$\begin{array}{c}\text { 負債感得点 } \\
\text { [1-7] } \\
M(S D)\end{array}$} \\
\hline & 同 & 異 & \\
\hline 負債感高群 & 0 & 10 & 5. $40(0.97)$ \\
\hline 負債感低群 & 2 & 8 & $1.60(0.97)$ \\
\hline
\end{tabular}

負債感得点の中央値 (3.5) で負債感高群と低群に分けた。 そして，パートナーと異なる色のペンを選んだ人数を群ごと に算出した (Table 1)。その結果, 負債感高群の全員がパー トナーと異なる色のペンを選択していた。さらに，負債感低 群においてパートナーと異なる色のペンを選択しなかった 2 名の負債感得点は, どちらも理論的最小值であり「全く当て はまらない」というラベリングの 1 であった。これらの結果 は, 負債感を感じやすいほど貢献量明確化行動を行いやすく なるという予測を支持している。

その一方で, 負債感低群であるにも関わらずパートナーと 異なる色のペンを選択した者が 8 名おり, そのうちの 5 名の 負債感得点は 1 であった。すなわち，負債感を感じていなく ても貢献量明確化行動を行う参加者が存在していた。

以上のことを総合すると, 負債感を感じることは貢献量明 確化行動の十分条件となる一方で, 負債感が弱いからといっ て必ずしも貢献量明確化行動が消失するわけではないという 結論が導き出される。負債感が弱い場合であっても, 例えば 自身の能力を正確に評価したいといった動機づけがあれば, 貢献量明確化行動がなされる可能性はある（Clark，1984）。 負債感は，そういった動機づけが無い者でも貢献量明確化行 動を行うようになる感情として位置づけることができる。

ただし本研究の限界点として, 負債感を感じやすくなる操 作のみを行っていた点が挙げられる。今後は, 負債感を感じ にくくなる操作も加えての検討が必要であると考えられる。

付記研究に用いた材料および当日発表資料は以下の URL で参照・ダウンロード可能。https://osf. io/5mp3v/

(Akitomo YAMAMOTO \& Masataka HIGUCHI) 